\title{
Effect of crude latex from Euphorbia tirucalli on DMBA- induced carcinogenesis
}

Poliana Ribeiro Barroso ${ }^{1 *}$, Flaviana Dornela Verli², Ricardo Lopes Rocha ${ }^{4}$, Nadia Lages Lima ${ }^{2}$, Bethania Alves de Avelar ${ }^{1,3}$ and Gustavo Eustaquio Brito Alvim de Melo $^{3}$

*Correspondence: poliana.barroso@ict.ufvjm.edu.br

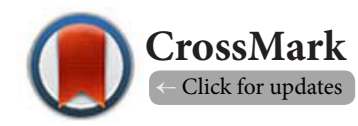

\author{
'Science and Technology Institute (ICT), Federal University of the Jequitinhonha and Mucuri Valleys (UFVJM), Diamantina, Minas \\ Gerais, Brazil. \\ 2Pathology Laboratory, Department of Basic Sciences, UFVJM, Brazil. \\ ${ }^{3}$ Immunology Laboratory, Pharmacy Department, UFVJM, Brazil. \\ ${ }^{4}$ Department of Dentistry, UFVJM, Brazil.
}

\begin{abstract}
Background: The aim of the present study was to determine the action of crude latex from Euphorbia tirucalli dissolved in DMSO in animal models of DMBA-induced carcinogenesis.

Methods: Three groups of hamsters received a topical application on edge of the tongue: 1) $0.5 \%$

DMBA+crude latex from E. tirucalli in 10\% DMSO; 2) 0.5\% DMBA+10\% DMSO; and 3) 0.5\% DMBA+saline solution. Macroscopic and histopathological analyses of the tumors were performed and antibodies were quantified using ELISA after 13 and 20 weeks of treatment.

Results: No statistically significant association was found between the development of cancer of the tongue mucosa and the production of antibodies in the different groups.

Conclusions: Although the data were non-significant, crude latex from E. tirucalli seems to reduce the aggressiveness and size of lesions, but further tests are required.

Keywords: Carcinogenesis, DMBA, tongue, Euphorbia tirucalli
\end{abstract}

\section{Introduction}

Euphorbia tirucalli (L.) is a native plant from Africa known popularly as "avelós" or "pencil tree" and is well adapted to the Brazilian Cerrado biome (savanna) $[1,2]$. The latex from this species is commonly used in traditional medicine [3] for the treatment of cancer [2,4-7]. This substance is also reported to have immunomodulatory [7,8], analgesic [9], angiogenic [10], antimicrobial [11], antimutagenic and antirheumatic [12] properties.

However, studies have reported the toxicity of this latex to skin and mucous membranes $[13,14]$ due to the presence of phorbol esters in species of the family Euphorbiaceae $[5,15]$. As there is controversy regarding the anticarcinogenic effects and modulatory activity of the latex from E. tirucalli in cases of carcinogenesis [16-18,34], studies are needed to demonstrate its activity. Thus, the aim of the present study was to determine the carcinogenic and/or anticarcinogenic action of the crude latex from E. tirucalli in vivo in a model of carcinogenesis induced by 9,10-dimethyl-1,2-benz-anthracene (DMBA) using histopathological analysis and an immunoassay.

\section{Materials and methods}

\section{Sample and experimental groups}

The use of animals in this study was in accordance with national and international legislation. The sample comprised 60 male and female hamsters (Mesocricetus auratus) aged 90 days with a mean body weight of $158.5 \mathrm{~g}$. The animals were acquired from the animal housing facility of the René Rachou Research Center of the Oswaldo Cruz Foundation and acclimatized in the laboratory for 14 days at room temperature and humidity under a 12-hour light-dark cycle in plastic cages $(60 \times 50 \times 22$ $\mathrm{cm}$ ) with free access to ration and water. Each cage was lined with wood shavings, contained a maximum of five animals and was cleaned twice per week. The animals were individually weighed at 3, 5, 7, 9, 11, 13, 15, 17, 19 and 20 weeks using an analytical scale (Gehaka ${ }^{\oplus}$, model BG 440). 
The hamsters were randomly divided into three groups of 20 animals each: 1) Euphorbia group - $0.5 \%$ DMBA+crude latex from E. tirucalli in 10\% dimethyl sulfoxide (DMSO); 2) DMSO group - $0.5 \%$ DMBA+10\% DMSO; and 3) DMBA group - $0.5 \%$ $\mathrm{DMBA}+$ saline solution. The groups were subdivided based on evaluation times ( 13 and 20 weeks).

\section{Test preparations}

The carcinogen DMBA (Sigma-Aldrich', St. Louis, MO, USA) was diluted in acetone to obtain a solution with a concentration of $0.5 \% \mathrm{p} / \mathrm{v}$. All days before application, the crude latex from E. tirucalli was collected and diluted in DMSO to obtain a solution with a concentration of $10 \% \mathrm{v} / \mathrm{v}$.

\section{Experimental protocol}

The substances were topically administered to the right lateral edge of the tongue using a $\mathrm{N}^{\circ} 1$ camel hair brush (Tigre $^{\oplus}$, San Paulo, Brazil). The application of DMBA was alternated every 24 hours with DMSO, crude latex from E. tirucalli and saline solution, depending on the test group. There was no application of any substance once a week. Each daily topical application consisted of four consecutive brushings. Excess substance was removed from the brush prior to the application to avoid accidental swallowing by the animals.

One day prior to euthanasia in each experimental period, a clinical analysis was performed of alterations of the lingual mucosa. The types of clinical alterations examined were based on the method proposed by Lima and Taveira [19], with modifications: diffuse erythematosus or diffuse whitish lesions (alterations of a reddish or whitish coloration); white plaque, characterized by a flat, white, well-circumscribed elevation; diffuse whitish berry-shaped lesions (alterations in color and texture, with small rounded irregularities on an opacified surface); verrucous plaque, characterized by a flat circumscribed elevation with a papillomatous surface; exophytic lesion; nodular or tumor mass. Calipers (Jon', São Paulo, Brazil) were used for the measurements of length ( $x$ axis) and width (y axis) of the plaque-type alterations. Measurements of the exophytic lesions also included depth (z axis). The area of the plaques and volume of the exophytic lesions were calculated as $A=\pi . x / 2 . y / 2$ and $V=3 / 4 . \pi . x y z$, respectively.

At each evaluation time, ten hamsters from each group were anesthetized with xylazine $(10 \mathrm{mg} / \mathrm{kg}$ of body weight) and ketamine ( $200 \mathrm{mg} / \mathrm{kg}$ of body weight) for euthanasia. After decapitation, the tongues were dissected and fixed in a $10 \%$ buffered formalin solution for 48 hours. The specimens were embedded in paraffin, cut, dehydrated in alcohol, cleared in xylol and stained with hematoxylin and eosin (HE).

The histological analysis was performed by a single examiner using an optical microscope (Olympus BX 41, Shinjuku-Ku, Tokyo, Japan) at different magnifications. The histological alterations encountered were classified based on the presence and number of structural and cytological alterations [21]. The classification of the degree of squamous epithelial dysplasia with the presence of structural and cytological alterations was based on the criteria established by Katz et al. [20] and Barnes et al. [21]. The degree of malignancy of squamous cell carcinomas was classified based on Johnson et al. [22]. The mean occurrence of structural and cytological alterations in the epithelium was calculated for squamous epithelial dysplasia. The histological area of the squamous cell carcinomas was calculated using the Motic Images Plus program, version 2.0 (Motic ${ }^{\circ}$ China Group CO. LTD., Copyright ${ }^{\circ}$ 2007, Guiyang, China).

\section{Evaluation of antibody production}

In the initial phase of treatment, all animals were immunized with ovalbumin and submitted to further immunization seven days before euthanasia for the formation of antigen-specific antibodies. Serum samples were obtained and assessed using a standard enzyme-linked immunosorbent assay (ELISA). ELISA plates were coated overnight at $4^{\circ} \mathrm{C}$ with $50 \mu \mathrm{g} / \mathrm{mL}$ of ovalbumin antigen per well in $\mathrm{Na}_{2} \mathrm{CO}_{3}$ buffer, $\mathrm{pH}$ 9.6. The plates were washed with phosphate-buffered saline containing $0.05 \%$ Tween-20 (PBS-T) and incubated overnight with PBS containing $5 \%$ casein solution and $0.01 \%$ azide (PBS-L), rewashed and incubated for 1 hour with dilutions of mouse antisera starting at $1 / 16$ in $0.5 \%$ PBS-L solution, washed again and incubated with hamster anti-mouse globulins (anti-lgG) for 1 hour, rewashed and incubated with streptavidin (1:5000) and $\mathrm{H}_{2} \mathrm{O}_{2}$ in the presence of orthophenylene diamine (OPD) in sodium citrate buffer, $\mathrm{pH} 5.0$, for 10 minutes. The reactions were interrupted by the addition of $2 \mathrm{M}$ of $\mathrm{H}_{2} \mathrm{SO}_{4}$ and optical densities were read in an ELISA reader (Molecular Devices ${ }^{\circledR}$, model SPECTRA MAX 190) with absorbance at $492 \mathrm{~nm}$ and $450 \mathrm{~nm}$.

\section{Statistical analysis}

The data were tabulated with the aid of the SPSS 17.0 program (SPSS Inc, Chicago, Illinois, USA). Normality tests were performed prior to the application of statistical analyses. Repeated-measure one-way analysis of variance (ANOVA) was used to determine changes in the mean body weight of the animals. The chi-square test was used to compare the occurrence of clinical and histological alterations among the groups. For the immunological evaluation, the variance of the data and the confidence interval were determined using ANOVA with Dunnet's post hoc tests. For both tests, a p-value $<0.05$ was considered indicative of statistical significance.

\section{Results \\ Body weight}

The mean body weight of the animals reduced throughout the course of the study. No linear progression in reduction occurred, as weight remained nearly constant the first 13 weeks and began to reduce in the following weeks. However, mean weight was higher in the DMSO and Euphorbia groups than the DMBA group (Figure 1). 


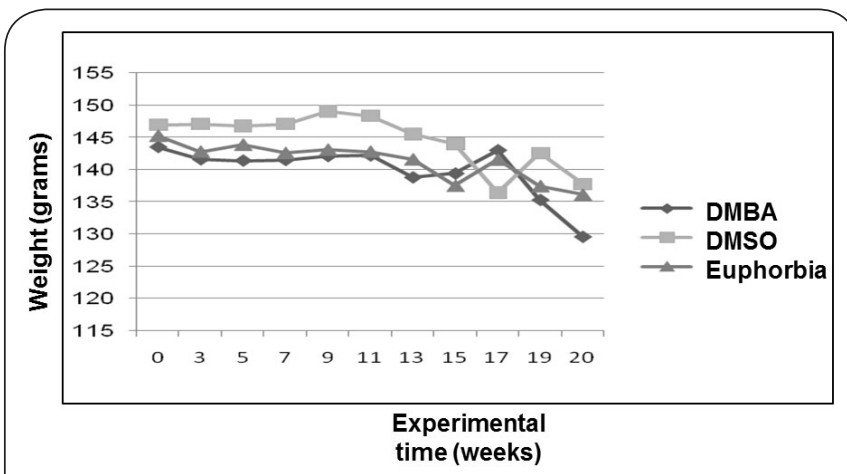

Figure 1. Weight (grams) X experimental time (weeks). Mean body weight of different groups during experimental periods. DMBA: 9,10-dimethyl-1,2-benz-anthracene; DMSO: dimethyl sulfoxide; Euphorbia: crude latex from E. tirucalli.

\section{Macroscopic clinical alterations}

At the 13-week macroscopic analysis, most lesions were in the form of whitish plaque, whereas exophytic forms were prevalent at 20 weeks (Figure 2). During the experiment, a few animals died in the Euphorbia and DMSO groups: one animal died in the first four weeks and three died in the three last weeks.

\section{Histopathology of epithelium at 13 and 20 weeks}

Three animals in the Euphorbia group (Week 12 and 18) and one animal in DMSO group (week 17) exhibited extensive cachexia and subsequently died. The animals that died were excluded from the clinical and cytological analysis of the lesions (Table 1). No statistically significant differences were found among the groups regarding different types of clinical and

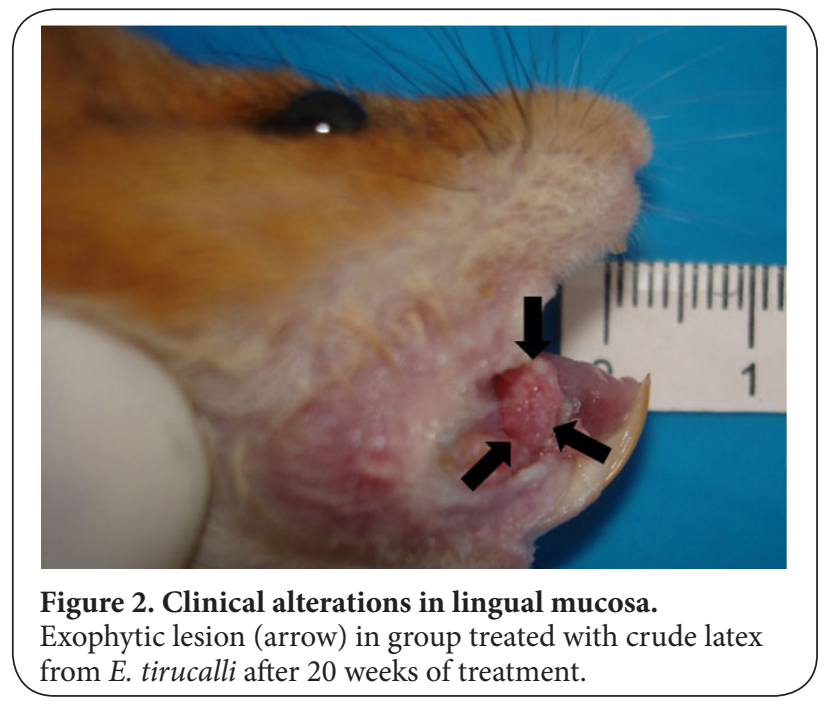

cytological alterations or respective mean areas or volumes at the two evaluation times (Weeks 13 and 20).

Regarding lesions at 13 weeks, a greater occurrence of dysplastic lesions was found, especially mild dysplasia (13 cases; $44.8 \%$ ) and moderate dysplasia ( 12 cases; $41.4 \%$ ). The structural alterations found in cases of mild squamous epithelial dysplasia (SED) in the DMSO and Euphorbia groups were irregular epithelial stratification and a loss of polarity. The cytological alterations found were increases in the nucleusto-cytoplasm ratio, number of nuclei and nucleus size and hyperchromasia. The presence of drop-shaped epithelial projections and increases in the number of atypical mitoses and white plaque characterized by a flat white well-circumscribed elevation and diffuse whitish berry-shaped lesions were only found in cases of mild SED in the DMBA group.

Table 1. Distribution of histopathological aspects of lesions from DMBA-induced oral carcinogenesis on tongue of hamsters after 13 and 20 weeks of treatment.

\begin{tabular}{|c|c|c|c|c|c|c|c|c|}
\hline \multirow[t]{3}{*}{ Histopathological descriptions } & \multicolumn{8}{|c|}{ Experimental time } \\
\hline & \multicolumn{4}{|c|}{13 weeks $(n=29)$} & \multicolumn{4}{|c|}{20 weeks $(n=27)$} \\
\hline & $\begin{array}{l}\text { Euphorbia } \\
\left(\mathbf{n}=9^{*}\right)\end{array}$ & $\begin{array}{l}\text { DMBA } \\
(n=10)\end{array}$ & $\begin{array}{l}\text { DMSO } \\
(n=10)\end{array}$ & $p$-value & $\begin{array}{l}\text { Euphorbia } \\
(\mathbf{n}=8 \dagger)\end{array}$ & $\begin{array}{l}\text { DMBA } \\
(n=10)\end{array}$ & $\begin{array}{l}\text { DMSO } \\
\left(n=9^{*}\right)\end{array}$ & $p$-value \\
\hline $\begin{array}{l}\text { Hyperplasia and hyperkeratosis } \\
\text { with absence of atypia } n(\%)\end{array}$ & $1(11.1)$ & $1(10.0)$ & -- & 0.374 & -- & -- & -- & -- \\
\hline SED - Mild n(\%) & $3(33.3)$ & $4(40.0)$ & $6(60.0)$ & 0.395 & $1(12.5)$ & -- & -- & -- \\
\hline SED - Moderate n(\%) & $4(44.4)$ & $5(50.0)$ & $3(30.0)$ & 0.106 & $1(12.5)$ & -- & -- & -- \\
\hline SED - Severe $n(\%)$ & $1(11.1)$ & -- & -- & -- & -- & $1(10.0)$ & $1(11.1)$ & 0.632 \\
\hline SCC - Microinvasive n(\%) & -- & -- & $1(10.0)$ & 0.374 & $3(37.5)$ & - & $2(22.2)$ & 0.250 \\
\hline SCC - Mild n(\%) & -- & -- & -- & -- & $2(25.0)$ & $5(50.0)$ & $3(33.3)$ & -- \\
\hline SCC - Moderate n(\%) & -- & -- & -- & -- & -- & $3(30.0)$ & $1(11.1)$ & -- \\
\hline SCC - Severe n(\%) & -- & -- & -- & -- & $1(12.5)$ & $1(10.0)$ & $2(22.2)$ & -- \\
\hline SCC invasive & -- & -- & -- & -- & -- & -- & -- & 0.089 \\
\hline
\end{tabular}

Chi-square test

*death of 1 animal; $\uparrow$ death of 2 animals; SED: squamous epithelial dysplasia; SCC: squamous cell carcinoma 
In cases of moderate SED in the Euphorbia group, the structural alterations were irregular epithelial stratification and the cytological alterations were a loss of polarity, a change in cell size, an increase in nucleus size, hyperchromasia and pleomorphism. Irregular epithelial stratification with dyskeratosis and hyperkeratosis, denominated Darier's dysplasia, occurred in only one case (Figure 3A). The structural and cytological alterations for moderate SED in the DMSO and DMBA groups were irregular epithelial stratification, increases in the nucleus-to-cytoplasm ratio, number of nuclei and nucleus size and hyperchromasia. Drop-shaped epithelial projections and hyperkeratosis occurred in the DMBA group (Figure 3B).

One case of hyperplasia and hyperkeratosis was found in the DMBA (10\%) and Euphorbia (11.1\%) groups at 13 weeks. The alterations were an increase in density in the stratum corneum and the number of cells in other extracts, with no morphological cell alterations. The occurrence of dysplastic lesions was lower in the Euphorbia group (eight cases; $88.8 \%$ ) and similar in the DMBA and DMSO groups (nine cases each; 90\%) (Table 1). However, only one case of severe SED was found in the Euphorbia group, with increases in the nucleus-to-cytoplasm ratio, number of atypical mitoses and nucleus size and number as well as hyperchromasia and total disruption of the epithelial layers (Figure $3 \mathrm{C}$ ). A case of microinvasive squamous cell carcinoma (SCC) was found in the DMSO group, with superficial invasion of neoplastic epithelial cells to the connective tissue.

At Week 20, premalignant lesions were found in two cases (25\%) in the Euphorbia group and one case in the DMBA (10\%) and DMSO (11.1\%) groups. In the Euphorbia group, the premalignant lesions were mild and moderate SED ( $12.5 \%$ each), with presence of irregular epithelial stratification, the loss of polarity, increases in the nucleus-to-cytoplasm ratio, nucleus size and number and hyperchromasia. In the DMSO and DMBA groups the lesions were severe SED and the structural and cytological alterations were irregular epithelial stratification, the loss of polarity, increases in the nucleus-to-cytoplasm ratio, number of nuclei and nucleus size and hyperchromasia.

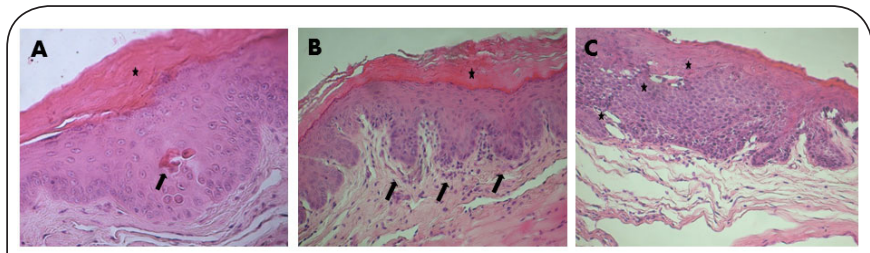

Figure 3. Histological alterations at week 13 in different groups.

A: Moderate squamous epithelial dysplasia (Darier type) with dyskeratosis (arrow) and hyperkeratosis (star) in Euphorbia group (H\&E, x200); B: Moderate squamous epithelial dysplasia with presence of drop-shaped epithelial projections (arrow) and hyperkeratosis (star) in DMBA group (H\&E, x100); C: Intense squamous epithelial dysplasia with total disruption of epithelial layers (star) in Euphorbia group (H\&E, x200). H\&E: hematoxylin and eosin.
The Euphorbia group showed fewer malignant lesions at 20 weeks $(75 \%)$ in comparison to the DMSO (88.9\%) and DMBA (90\%) groups (Table 1). In the DMSO and DMBA groups, cases of microinvasive SCC were found, with the occurrence of superficial invasion of neoplastic epithelial cells to the connective tissue adjacent to the epithelium (Figure 4A). In all groups, cases of small SCC were found, with epithelial projections toward the surface, whereas the invasive SCC exhibited exophytic growth and well-differentiated degrees of malignancy. The lesions exhibited invasion in all tissues, with an increased number of atypical mitoses and the presence of keratin pearls (Figure 4B). No statistically significant difference among groups was found with regard to the development of cancer in the oral mucosa at Weeks 13 and 20 ( $p>0.05$, chi-square test).

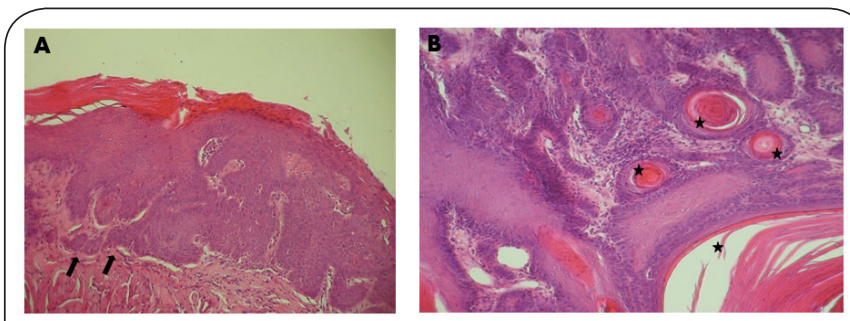

Figure 4. Histological alterations at Week 20 in different groups.

A: Microinvasive carcinoma with superficial invasion to connective tissue (arrow) in DMSO group (H\&E, x100); B: Squamous cell carcinomas with presence of keratin pearls (star) in DMBA group (H\&E, x200). H\&E: hematoxylin and eosin.

\section{Immunological evaluation}

At Week 13 , no statistically significant differences among groups were found regarding the production of antibodies (Figure 5A). At Week 20, the animals treated with the crude latex from E. tirucalli had a lower production of antibodies when compared to the DMBA group. However, this reduction was also found in the DMSO group (Figure 5B).

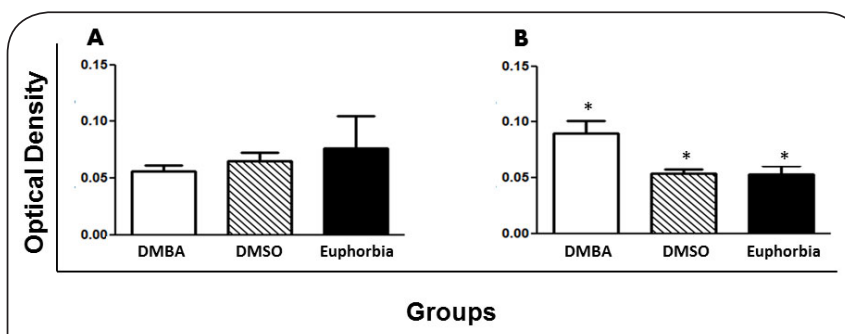

Figure 5. Optical density of production of antibodies by different groups.

A: Production of antibodies in different groups after 13 weeks of treatment; B: Production of antibodies in different groups after 20 weeks of treatment. Data expressed as mean \pm SEM * statistically significant $(\mathrm{p}<0.05$. ANOVA with Dunnet's post hoc test). 
Barroso et al. Journal of Histology \& Histopathology 2017,

http://www.hoajonline.com/journals/pdf/2055-091X-4-3.pdf

doi: 10.7243/2055-091X-4-3

\section{Discussion}

Cancer is the second most fatal form of disease behind cardiovascular disease [23]. The development of cancer is a multistep process with three distinct phases: initiation, promotion and progression [24]. The carcinogen DMBA is a chemical initiator and promoter of carcinoma in the oral mucosa [25] through production of free radicals (byproducts of its metabolism), leading to the damage of DNA, cell membranes and proteins as well as the dysregulation of anti-apoptotic mediators [26,27]. After the topical application of $0.5 \%$ DMBA in acetone for a period of 20 weeks, histopathological alterations similar to cancerous lesions in humans are found on the oral mucosa [25]. Other studies involving this methodology demonstrate this procedure to be effective in the evaluation of natural products using a carcinogenic model $[25,28]$.

The crude latex from $E$. tirucalli is used in traditional medicine $[3,5,29]$ for the treatment of several types of cancer $[5,6]$. In the present study, no significant differences were found between the different substances used regarding the anticarcinogenic effect on the oral mucosa after 13 and 20 weeks. However, reductions in the aggressiveness and size of the tumors were found in the Euphorbia group.

At Week 20, loss weight was found in all groups, but was more pronounced in the DMBA group. It is possible what this reduction is associated with the toxic action of the different substances applied, especially the carcinogen [30]. Lajolo et al. [30] found an increase in the weight of animals in the test groups when the application of DMBA was suspended.

The histopathological results showed that the topical application of crude latex from E. tirucalli promoted the reduction in the progression of oral carcinoma, as evidenced by the less aggressive nature of carcinoma in the Euphorbia group when compared the other experimental groups. In a carcinogenesis model in the peritoneal cavity of rats, Valadares et al. [2] found that the oral administration of an alcoholic extract of E. tirucalli promoted an increase in the production and functional activity of macrophages and granulocytes as well as a decrease in levels of prostaglandin E2, resulting in a decrease in tumors and the extended survival of the animals. It is probable that such a reduction in the progression of SCC is related to the chemical constitution of this latex. In other in vitro studies, euphol, which is a triterpene alcohol isolated from E. tirucalli, demonstrated high cytotoxicity to cancer cells. The authors suggest that euphol inhibits cyclins involved in the cell cycle and upregulates pro-apoptotic proteins $[5,6,31]$.

Regarding the immunological evaluation, the results indicate that the crude latex from E. tirucalli does not exert a direct action on the humoral immune response. Recent studies have shown that this plant has an immunomodulatory effect via the stimulation of type 1 cytokine production (INF- $\gamma$ and TNF- $\alpha$ in leukocytes), which favors the cellular immune response [8]. It has also been shown that animals with induced tumors from EL4 or EG7 cell lines and rIFN- $\gamma$ knockout or deficiency in the production of IFN- $\gamma$ did not respond to chemotherapy, exhibiting the normal production of this cytokine and its receptors when compared to the control group [32]. This demonstrates the importance of IFN- $\gamma$ to an effective response to chemotherapy. It is therefore possible that the antitumor mechanism of action observed for E. tirucalli is through the stimulation of the cellular immune response. Furthermore, studies have shown the immunomodulatory effect of the solvent DMSO [33], which exerts a significant effect on the humoral immune response. Thus, the solvent itself favored the non-increase in antibody production in the presence of the latex.

\section{Conclusion}

The crude latex from $E$. tirucalli seems decrease the aggressiveness and size of oral carcinomas, although no statistically significant differences were found in the development of cancer of the tongue mucosa or the production of antibodies in the different groups and at the different times assessed. The DMSO solvent may have interfered with the immunomodulatory action of the latex. Thus, further studies are needed to evaluate the immunomodulatory properties of the crude latex from E. tirucalli.

\section{List of abbreviations}

ANOVA: Analysis of variance

DMBA: 9,10-dimethyl-1,2-benz-anthracene

DMSO: dimethyl sulfoxide

DNA: Deoxyribonucleic acid

EG7:Cell line OVA-transfected EL4 thymoma

EL4: Cell Line murine lymphoblast from blood

ELISA: Enzyme Linked Immuno Sorbent Assay

ICT: Science and Technology Institute

INF- $\mathrm{:} \mathrm{Interferon} \mathrm{gamma}$

PBS-L: PBS containing 5\% casein solution and $0,01 \%$ azide

PBS-T: Phosphate-buffered saline containing 0.05\% Tween-20

OPD: Orthophenylene diamine

SCC: Squamous Cell Carcinoma

SED: Squamous epithelial dysplasia

TNF-a: Tumor necrosis factor-alpha

rIFN-ү: Receptor Interferon gamma

UFVJM: Federal University of the Jequitinhonha and Mucuri Valleys

\section{Competing interests}

The authors declare that they have no competing interests.

\section{Authors' contributions}

\begin{tabular}{|l|c|c|c|c|c|c|}
\hline Authors' contributions & PRB & FDV & RLR & NLL & BAA & GEBAM \\
\hline Research concept and design & $\checkmark$ & $\checkmark$ & -- & -- & -- & $\checkmark$ \\
\hline $\begin{array}{l}\text { Collection and/or assembly of } \\
\text { data }\end{array}$ & $\checkmark$ & $\checkmark$ & -- & $\checkmark$ & -- & -- \\
\hline Data analysis and interpretation & $\checkmark$ & $\checkmark$ & $\checkmark$ & $\checkmark$ & $\checkmark$ & -- \\
\hline Writing the article & $\checkmark$ & $\checkmark$ & -- & -- & -- & -- \\
\hline Critical revision of the article & $\checkmark$ & $\checkmark$ & -- & -- & $\checkmark$ & $\checkmark$ \\
\hline Final approval of article & $\checkmark$ & $\checkmark$ & -- & -- & $\checkmark$ & $\checkmark$ \\
\hline Statistical analysis & -- & -- & $\checkmark$ & -- & -- & -- \\
\hline
\end{tabular}

Acknowledgement and funding

The authors would like thank the State of Minas Gerais Research 
Support Foundation (FAPEMIG) for funding this project and all the faculty members of the Immunology and Pathology Laboratory who contributed to this work. In special to students of pharmacy Alexandre Sathler Avelar and Marcos Vinícius Chaves Mateus.

Publication history

EIC: Gaetano Giuseppe Magro, University of Catania, Italy. Received: 10-Feb-2017 Final Revised: 28-Mar-2017

Accepted: 12-Apr-2017 Published: 26-Apr-2017

\section{References}

1. Oliveira AP and Nepumuceno JC. Evaluationof genotoxic and antigenotoxic effects of the Avelós (E. tirucalli) in Drosophila metanogaster. Biosci. J. 2004; 20:179-86.

2. Valadares MC, Carrucha SG, Accorsi W and Queiroz ML. Euphorbia tirucalli L. modulates myelopoiesis and enhances the resistance of tumour-bearing mice. Int Immunopharmacol. 2006; 6:294-9. | Article | PubMed

3. de Melo JG, Santos AG, de Amorim EL, do Nascimento SC and de Albuquerque UP. Medicinal plants used as antitumor agents in Brazil: an ethnobotanical approach. Evid Based Complement Alternat Med. 2011; 2011:365359. | Article | PubMed Abstract | PubMed FullText

4. Madureira AM, Ferreira MJ, Gyemant N, Ugocsai K, Ascenso JR, Abreu PM, Hohmann J and Molnar J. Rearranged jatrophane-type diterpenes from euphorbia species. Evaluation of their effects on the reversal of multidrug resistance. Planta Med. 2004; 70:45-9. | Article | PubMed

5. Lin MW, Lin AS, Wu DC, Wang SS, Chang FR, Wu YC and Huang YB. Euphol from Euphorbia tirucalli selectively inhibits human gastric cancer cell growth through the induction of ERK1/2-mediated apoptosis. Food Chem Toxicol. 2012; 50:4333-9. | Article | PubMed

6. Wang L, Wang G, Yang D, Guo X, Xu Y, Feng B and Kang J. Euphol arrests breast cancer cells at the $\mathrm{G} 1$ phase through the modulation of cyclin D1, p21 and p27 expression. Mol Med Rep. 2013; 8:1279-85. | Article | PubMed

7. Chen $\mathrm{CL}$, Chen $\mathrm{YP}$, Lin $\mathrm{MW}$, Huang $\mathrm{YB}$, Chang FR, Duh $\mathrm{TH}$, Wu DC, Wu WC, Kao YC and Yang PH. Euphol from Euphorbia tirucalli Negatively Modulates TGF-beta Responsiveness via TGF-beta Receptor Segregation inside Membrane Rafts. PLoS One. 2015; 10:e0140249. | Article | PubMed Abstract | PubMed FullText

8. Avelar BA, Lélis FJN, Avelar RS, Weber M, Souza FEM, Lopes MTP, Martins FOA and Brito MGEA. The crude latex of Euphorbia tirucalli modulates the cytokine response of leukocytes, especially CD4+ T lymphocytes. Rev. Bras. Farmacogn. 2011; 21:662-7. | Article

9. Khan AQ, Ahmed Z, Kazml NU and Malik A. Further Triterpenes from the Stem Bark of Euphorbia tirucalli. Planta Med. 1987; 53:577. | Article | PubMed

10. Bessa G, Melo-Reis PR, Araujo LA, Mrue F, Freitas GB, Brandao ML and Silva Junior NJ. Angiogenic activity of latex from Euphorbia tirucalli Linnaeus 1753 (Plantae, Euphorbiaceae). Braz J Biol. 2015; 75:752-8. | Article | PubMed

11. de Oliveira LF, Fuentefria AM, Klein Fda S and Machado MM. Antifungal activity against Cryptococcus neoformans strains and genotoxicity assessment in human leukocyte cells of Euphorbia tirucalli L. Braz J Microbiol. 2014; 45:1349-55. | PubMed Abstract | PubMed FullText

12. Bani S, Kaul A, Khan B, Gupta VK, Satti NK, Suri KA and Qazi GN. Antiarthritic activity of a biopolymeric fraction from Euphorbia tirucalli. J Ethnopharmacol. 2007; 110:92-8. | Article | PubMed

13. Shlamovitz GZ, Gupta M and Diaz JA. A case of acute keratoconjunctivitis from exposure to latex of Euphorbia tirucalli (pencil cactus). J Emerg Med. 2009; 36:239-41. | Article | PubMed

14. Kumar A, Prasad M, Mishra D, Srivastav SK and Srivastav AK. Toxicity of aqueous extract of Euphorbia tirucalli latex on catfish, Heteropneustes fossilis. Ecotoxicol Environ Saf. 2010; 73:1671-3. | Article | PubMed

15. Lin SJ, Yeh CH, Yang LM, Liu PC and Hsu FL. Phenolic compounds from Formosan Euphorbia tirucalli. J. Chin. Chem. Soc. 2001; 48:105-8. | Article

16. van den Bosch C, Griffin BE, Kazembe P, Dziweni C and Kadzamira L. Are plant factors a missing link in the evolution of endemic Burkitt's lymphoma? Br J Cancer. 1993; 68:1232-5. | PubMed Abstract | PubMed FullText

17. Imai S, Sugiura M, Mizuno F, Ohigashi H, Koshimizu K, Chiba S and Osato T. African Burkitt's lymphoma: a plant, Euphorbia tirucalli, reduces Epstein-Barr virus-specific cellular immunity. Anticancer Res. 1994; 14:933-6. | Article | PubMed

18. MacNeil A, Sumba OP, Lutzke ML, Moormann A and Rochford R. Activation of the Epstein-Barr virus lytic cycle by the latex of the plant Euphorbia tirucalli. Br J Cancer. 2003; 88:1566-9. | Article | PubMed Abstract | PubMed FullText

19. Lima NL and Taveira LAA. Study of morphologic changes caused by concomitant induction of DMBA and heavy alcoholic drinks in oral chemical carcinogenesis. Rev Fac Odontol Bauru. 1999; 7:61-6.

20. Katz HC, Shear M and Altini M. A critical evaluation of epithelial dysplasia in oral mucosal lesions using the Smith-Pindborg method of standardization. J Oral Pathol. 1985; 14:476-82. | Article | PubMed

21. Barnes L, Eveson JW, Reichart P and Sidransky DL. WHO classification head and neck tumours. Lyon: IARC Press. 2005.

22. Johnson N, Franceschi S, Ferlay J, Ramadas K, Schmid S, MacDonald DG, Bouquot JE and Slootweg PJ. Squamous cell carcinoma. In: Barnes $L$, Eveson JW, Reichart P, Sidransky D. WHO classification head and neck tumours. Lyon: IARC Press. 2005; 1:168-75.

23. WHO. Global status report on noncommunicable diseases 2014. Library Cataloguing-in-Publication Data. Geneva, 2014.

24. Boutros R, Lobjois $V$ and Ducommun B. CDC25 phosphatases in cancer cells: key players? Good targets? Nat Rev Cancer. 2007; 7:495-507. | Article | PubMed

25. Kathiresan S and Govindhan A. [6]-Shogaol, a Novel Chemopreventor in 7,12-Dimethylbenz[a]anthracene-induced Hamster Buccal Pouch Carcinogenesis. Phytother Res. 2016; 30:646-53. | Article | PubMed

26. Silvan S and Manoharan S. Apigenin prevents deregulation in the expression pattern of cell-proliferative, apoptotic, inflammatory and angiogenic markers during 7,12-dimethylbenz[a]anthracene-induced hamster buccal pouch carcinogenesis. Arch Oral Biol. 2013; 58:94-101. | Article | PubMed

27. Manoharan S, Rajasekaran D, Prabhakar MM, Karthikeyan S and Manimaran A. Modulating Effect of Enicostemma littorale on the Expression Pattern of Apoptotic, Cell Proliferative, Inflammatory and Angiogenic Markers During 7, 12-Dimethylbenz (a) Anthracene Induced Hamster Buccal Pouch Carcinogenesis. Toxicol Int. 2015; 22:130-40. I Article | PubMed Abstract | PubMed FullText

28. Ricardo LR, Ribeiro BP, Soares SA, Lages LN, Oliveira FF and Dornela VF. Effects of propolis on lingual mucosa response of hamsters submitted to experimental carcinogenesis. Zhong Xi Yi Jie He Xue Bao. 2012; 10:144350. | Article | PubMed

29. Dutra RC, Campos MM, Santos AR and Calixto JB. Medicinal plants in Brazil: Pharmacological studies, drug discovery, challenges and perspectives. Pharmacol Res. 2016; 112:4-29. | Article | PubMed

30. Lajolo C, Giuliani M, Sgambato A, Majorano E, Lucchese A, Capodiferro S and Favia G. N-(4-hydroxyphenyl)all-trans-retinamide (4-HPR) high dose effect on DMBA-induced hamster oral cancer: a histomorphometric evaluation. Int J Oral Maxillofac Surg. 2008; 37:1133-40. | Article | PubMed

31. Choene M and Motadi L. [Validation of the Antiproliferative Effects of 
Barroso et al. Journal of Histology \& Histopathology 2017,

http://www.hoajonline.com/journals/pdf/2055-091X-4-3.pdf

Euphorbia tirucalli Extracts in Breast Cancer Cell Lines]. Mol Biol (Mosk). 2016; 50:115-27. | Article | PubMed

32. Ghiringhelli F, Apetoh L, Tesniere A, Aymeric L, Ma Y, Ortiz C, Vermaelen K, Panaretakis T, Mignot G, Ullrich E, Perfettini JL, Schlemmer F, Tasdemir E, Uhl M, Genin P, Civas A, Ryffel B, Kanellopoulos J, Tschopp J, Andre F, Lidereau R, McLaughlin NM, Haynes NM, Smyth MJ, Kroemer G and Zitvogel L. Activation of the NLRP3 inflammasome in dendritic cells induces IL-1beta-dependent adaptive immunity against tumors. Nat Med. 2009; 15:1170-8. | Article | PubMed

33. Santos NC, Figueira-Coelho J, Martins-Silva J and Saldanha C.

Multidisciplinary utilization of dimethyl sulfoxide: pharmacological, cellular, and molecular aspects. Biochem Pharmacol. 2003; 65:1035-41. | Article | PubMed

34. Machado MM, de Oliveira LF, Zuravski L, de Souza RO, Fischer P, Duarte $\mathrm{JA}$, Rocha MO, Guez CM, Boligon AA and Athayde ML. Evaluation of genotoxic and cytotoxic effects of hydroalcoholic extract of Euphorbia tirucalli (Euphorbiaceae) in cell cultures of human leukocytes. An Acad Bras Cienc. 2016; 88:17-28. | Article | PubMed

\section{Citation:}

Barroso PR, Verli FD, Rocha RL, Lima NL, Avelar BAd and Melo GEBAd. Effect of crude latex from Euphorbia tirucalli on DMBA-induced carcinogenesis. J Histol Histopathol. 2017; 4:3.

http://dx.doi.org/10.7243/2055-091X-4-3 